\title{
Editorial
}

\section{Global Labour Studies in the Pandemic: Notes for an Emerging Agenda}

\author{
Maria Lorena Cook, Cornell University, USA \\ Madhumita Dutta, The Ohio State University, USA \\ Alexander Gallas, University of Kassel, Germany \\ Jörg Nowak, University College Dublin, Ireland \\ Ben Scully, University of the Witwaterstand, South Africa
}

\section{Shifting Fields of Visibility}

On 14 February 2020, four Harvard epidemiologists published a paper on the detection of COVID-19 cases around the world. Their "gold standard of near-perfect detection" was Singapore, a country that "has historically had very strong epidemiological surveillance and contact-tracing capacity and has shown in the COVID-19 epidemic evidence of a high sensitivity of case detection" (Niehus, De Salazar, Taylor and Lipsitch., 2020: 1, 3). On 21 April 2020, the New York Times reported that the case incidence in the city-state had doubled within the space of just a few days, turning it into the country with the highest number of infections in South East Asia (Beech, 2020).

What had gone wrong? Investigation revealed that the virus had spread in the dormitories of migrant workers. Singapore's population of over one million low-wage labourers from abroad works in construction, manufacturing, cleaning and logistics. They live in cramped conditions in dormitories located on the outskirts of the city where up to twenty people share a room (Beech, 2020; Ratcliffe, 2020a, 2020b). The "hidden abode of production" (Marx, 1976: 279), as well as the literal abodes in which workers' lives are reproduced, proved to be a more significant factor than the "gold standard" epidemiological practices of health officials.

The importance of poor working and living conditions for the spread of the virus can be identified across the globe. An example is meat processing, a sector known for employing migrant workers, endangering their health and paying low wages (Birke and Bluhm, 2020). Workers in this industry usually operate in close proximity to one another; if they are migrants, they often live in overcrowded housing and share vehicles on their way to work. It is known by now that the meat industry has contributed to spreading infections in Australia, Brazil, Britain, France, Germany, Ireland, the Netherlands and the United States (ABC News, 2020; Dutch News, 2020; France24, 2020; Jordan and Dickerson, 2020; Lakhani, 2020; Levitt, 2020; Mano, 2020; McSweeney, 2020; Staudemeier, 2020). Labour activists and scholars have pointed to similar risks for agricultural workers (Bonanese, 2020; Haedicke, 2020), many of whom are seasonal workers who have left their home countries and are faced with highly precarious employment and housing arrangements.

The situation of precarious migrant workers points to the more general question of the class nature of the pandemic. While many professionals continue to work from the relative safety of their homes, manual and precarious workers often travel on public transport and work side-by-side with their colleagues, facing a high risk of infection. Workers not entitled to sick pay usually have 
to continue working even if they are ill, which makes it harder for them to recover and puts their co-workers at risk (Bergfeld, 2020).

Importantly, the above examples demonstrate that the effects of the pandemic on workers expand far beyond the question of health risks at work or the workplace more generally. The question of production is intrinsically linked to the question of reproduction - that is, what kind of household workers and their dependents inhabit, how they ensure the ability to do waged work on a day-to-day basis, and what kinds of non-waged work need to be carried out in this process.

All of this renders into sharp relief two key traits of contemporary global capitalism. First, divisions of labour not only entail steep hierarchies and huge inequalities in access to resources they are matters of life and death. This concerns not just divisions of class, but also how they are articulated with gendered, racial, ethnic and caste divisions of labour, as the observations on households and migrant labour show. Second, the dependence of the world economy on workers is also a dependency on labour migration, despite nationalist mobilisations and political leaders' exhortations to close borders. The importance of migrant labour is not just visible in Singapore. The healthcare infrastructure and the networks of food production in most Northern countries would break down without workers from abroad (see below).

It follows that fields of visibility of work-related issues are rapidly shifting in this crisis. Certain groups of workers are overlooked until the material force of the pandemic briefly drags them into the limelight - workers in healthcare, grocery stores, delivery, sanitation, transportation, meatpacking and agriculture - only to be forgotten again as soon as there are novel sites and dynamics of the crisis. Other groups and issues are largely overlooked - for example: construction workers, utility workers, child and elder care workers; or issues such as the rapid adoption of digital technologies and their effects on the labour process; the effects of reduced hours, short-time working schemes or unemployment on workers who are not deemed "essential"; the consequences of overwork (and the modifications of labour law that facilitate it) for those who are "essential"; and the obstacles currently faced by unions and labour activists when it comes to campaigning, organising and mobilising for strike action.

In this situation, global labour studies is tasked with stabilising and expanding the existing fields of visibility. Crucially, this also involves shifting the focus to who is being pushed to, or has continuously remained on, the side-lines - making the hidden abodes visible. Building on a long tradition in materialist and feminist scholarship, a group of German activist scholars remarked that during the pandemic "some socially necessary types of work become visible", while "other vitally important types of work are ... rendered invisible" (Blauer Montag, 2020: 11, own translation). In our view, this insight is highly relevant for global labour studies.

\section{An Emerging Agenda for Global Labour Studies}

Our observations attest to the continued relevance of the academic project in which this Journal is engaged: the critical study of labour from a global perspective. Yet, we now take up this study in a very different world. The pandemic has swept through every country, but its full implications are unclear. We are in the midst of a deep historical rupture, where we are likely to face dramatic changes, a deepening of existing inequalities and injustices, and new forms of resistance and struggle all at once. In light of this, it is worth revisiting a topic that we discussed in our January editorial: what an agenda for global labour studies in the present day and age could look like. How might we reframe that agenda in light of the current crisis and the historical rupture it is likely to produce? Below we explore eight possible themes for further analysis. 


\section{How is the pandemic reconfiguring the global and the national?}

The importance of a global lens is reinforced by the crisis. Of course, the globalised nature of the world economy is nothing new. But the rapid spread of the virus around the world and the disruption to trade that has resulted from lockdown measures and closed borders both highlight in an unusually concrete way the centrality of global flows of people and goods to the basic functioning of economic activity. And the virus has revealed features of global interconnection which were not obvious before. For example, standard descriptions of globalisation from the past few decades would normally highlight the growing importance of global governance institutions. However, the crisis has shown the weakness and fragility of many global institutions. The situation of the World Health Organization (WHO) is a telling example. The willingness of nationalist leaders like Donald Trump to attack it in the midst of a global health crisis speaks to the fragility of global governance institutions in the current moment. Similarly, the European Union, which has long seemed to be one of the most robust examples of regional transnational coordination, has seen member states clearly placing national interests ahead of regional coordination and solidarity.

At the same time, the health crisis has laid bare the degree to which the global economy relies on global production networks and migrant labour. For example, health authorities around the world have suddenly started competing for personal protective equipment for healthcare workers. And once factories were closed in the first epicentre of the pandemic, Hubei province in China, carmakers across the planet had to interrupt production (EIU, 2020; Frew, 2020). A similar point can be made about migrant labour. A quarter of all hospital staff and a fifth of people working in health and social sectors in the United Kingdom were born outside the country, mirroring the perpetual reliance of the National Health Service (NHS) on recruits from abroad (Kotecha, 2019; Nuffield Trust, 2019). In Germany, agricultural firms successfully lobbied the government for authorisation to fly in 80000 workers from Eastern Europe to help with the asparagus harvest despite the fact that the borders were closed at the time (Bogoeski, 2020). The Italian government recently announced that it will provide hundreds of thousands of unauthorised migrant workers with temporary work permits to work in agriculture (Reuters, 2020). And in the United States, immigrant farmworkers were deemed "essential" workers, despite the fact that a large number of them are undocumented and still subject to deportation by US immigration officials (Jordan, 2020).

The concurrence of weakened global institutions and the continued significance of global production networks and migrant labour is important for labour scholars and workers' movements. Workers around the world have an interest in increased regulation of capital at transnational and global scales. The weakness of global responses, even in such a crisis moment, shows the scale of the challenge faced by any attempts to increase such global regulation in normal times.

Where global and national responses have faltered, the responses of sub-national levels of government have proven important to mitigating the effects of the crisis, both in health and economic terms. This is true even, or perhaps especially, in countries like the United States and Brazil, which have had disastrous national pandemic responses. Sub-national governments have long been important for workers' movements - for example, in campaigns for minimum wage increases at city and state levels in the United States, or in the inclusion of social and labour clauses in public procurement laws at the state level in Germany (Sarter, Sack and Fuchs, 2014; NELP, 2017).

These issues raise a number of questions for labour scholars. How will rising nationalism and an increasingly fragmented global governance affect the structure of the real economy? Are we entering a period of increased autarky, or will we see a continued expansion of economic 
globalisation alongside growing political nationalism? How is labour migration affected by the rise of nationalism and the disruption of transnational economic networks? What are the implications for transnational and global organisation and action by workers?

\section{How is the pandemic further destabilising distinctions between formal and informal sectors?}

The global pandemic has also made clear that precarity is not only a characteristic of certain types of "informal" work, but is a condition which is experienced by even the most "formal" wagedependent workers all over the world. For those who remain lucky enough to be exploited, as the old saying goes, the necessity of continued wage work increases their exposure to health risks. Beyond the health crisis, the economic consequences of the lockdowns are staggering to comprehend, and certain to produce lasting impacts. Already there is a deep economic crisis with millions of workers around the world plunged into unemployment. The International Labour Organization (ILO) expects the pandemic to destroy more than 300 million full-time jobs worldwide. In countries with fragmentary welfare systems, lockdowns do not just deprive workers of their jobs; in losing their income, workers also face dire poverty and hunger. The ILO (2020) warns that 1.6 billion informal workers are at risk of losing their livelihoods, nearly half of the global workforce.

It is not a stretch to assume that the proportion of the labour force engaged in informal work will expand, not only in those countries that have historically seen a large informal workforce but also in those where formal employment has been the norm. In Latin America, for instance, 54 per cent of the labour force worked in the informal economy prior to the onset of the pandemic. The economic crisis is expected to generate a significant increase in unemployment (from 8 to 11.5 per cent) as well as an expansion of poverty and extreme poverty in a region that had begun to make strides in reducing poverty and inequality in the 2000s (CEPAL/OIT, 2020). Women and youth, who are disproportionately represented in informal work, will be among those most affected by these trends. In the formal sector, we could see the exacerbation of features present before the pandemic, especially with regard to the incorporation of informal labour into larger companies' supply chains.

All of these developments should focus the attention of labour scholars on the increasingly blurred distinction between the categories of "informal" and "formal" or "precarious" and "secure". It seems more urgent than ever to examine labour regulations and forms of social policy that can offer protection to all types of workers. To realise such political goals, it will be necessary to understand points of both common interest and potential conflict between "formal" and "informal" workers.

\section{We're NOT "in it together": How has the pandemic exacerbated inequalities and sharpened the class divide?}

A few catchphrases that have become part of the daily lexicon during the time of COVID-19 are "We're in this together", "social distancing" and "flattening the curve". The assumption here being that we live in a society that is equal - socially, politically, economically - and therefore we must act, respond and experience the pandemic equally. This assumption depoliticises the historic and contemporary processes and relations of production/reproduction that are deeply fractured and hierarchical. As images and reports from across the world pour in, we see millions of such existing fractures resurfacing across and within nations. 
While the past few months have seen both superficial and substantive expressions of solidarity, the pandemic has blown away the façade of civility across nations from the Global North to the Global South. Deep-seated prejudices, biases and societal fractures have come to the surface. Ham-fisted lockdowns, xenophobic mob-inciting statements of national leaders, brutal enforcement of "social distancing", populist immigration policies, and the closing of national and state borders have been legitimised in the name of the pandemic. According to Human Rights Watch, the incidence of verbal and physical attacks targeting specific racial and religious groups and immigrants has increased across the globe. For instance, in Britain and the United States, across Europe, and in Kenya, Ethiopia and South Africa, there have been reports of harassment and attacks on Asians and people of Asian descent, most of whom are workers or owners of small businesses (Grierson, 2020; Human Rights Watch, 2020).

The pandemic has amplified existing inequalities along lines of class, race, gender and immigration status. In many countries, access to health insurance is restricted for many workers due to weak public infrastructures and the absence of public health insurance. For example, approximately 28 million people in the United States did not have health insurance in 2018, most of whom were members of low-income households (Tolbert, Orgera and Damico, 2019). In the United States, higher numbers of infections and deaths among African Americans, Latinx/Hispanics and indigenous Native Americans expose the continuing racial discrimination in housing, neighbourhoods, employment, education and health care, which makes certain groups of people more vulnerable than others. Crowded housing, chronic health conditions (leading to comorbidity), violence, institutional racism, evictions, income inequalities leading to stress and compromised immunity, employment in essential-service jobs (sanitation workers, janitors, food services, transportation and delivery services) - these factors put people of colour in the United States at a higher risk of poor health outcomes generally, and more so in times like this (Golden, 2020).

This inequality is reflected not only in differential access to health protection, but also in the ability to comply with stay-at-home orders and the likelihood of being subjected to employer directives to continue working or to return to work. The limited space that working families have at home has also made coping with lockdowns particularly hard. People affected by domestic violence, mostly women and children, are stuck in environments that have become even more dangerous, close to perpetrators of abuse and far from resources and allies. Home schooling creates an extra burden, particularly for women, and is an insurmountable challenge for people living in cramped surroundings with limited access to IT infrastructures and educational resources (Lewis, 2020; Scheiber, Schwartz and Hsu, 2020). The impacts of unemployment and access to social safety nets and emergency support measures are also felt unequally.

In India, the class divide has never been as stark and visible as it has been in these last few weeks since the lockdown was imposed. The lockdown forced millions of migrant labourers into unemployment. Many were stranded in the towns and cities where they work with little food or water. As public transport was no longer operational, people had to walk long distances over several days to reach their home villages. Hundreds died on these journeys (Pandey, 2020; Rao, 2020). The central government also planned to increase working hours from eight to twelve hours a day, the logic being that since the full workforce could not be allowed in the workplace in order to maintain "social distancing" and industries needed to start production, a reduced workforce and longer working hours could enable production to restart. Given the high rate of job loss among the adult population, there are also fears of children increasingly joining the informal workforce; their number already stands at a staggering 10 million, according to the 2011 census (Kundu, 2020).

These inequalities are visible not only within countries but across the globe as well, 
exacerbating the North-South divide. For instance, as Mexican workers fell sick and died due to COVID-19, the United States pressured Mexico into reopening the industrial plants that supply the US market (Linthicum, Fry and Minjares, 2020). Although the Mexican government decreed the closure of all non-essential enterprises, most of those firms kept producing non-essential goods like auto parts (Bacon, 2020). More than 400 workers in these plants have died of COVID-19, and 68 per cent of maquiladoras - factories in Mexico, usually near the border, that assemble products for the US market - in Baja California have carried on working during the crisis (London, 2020). Countries in a vulnerable position in the world economy may find it difficult to prioritise health concerns when faced with economic (and political) pressures from major trade partners and corporations.

Against this backdrop, it is important for labour scholars to map how relations of social domination such as class, race and race relations are being reconfigured in the crisis, and how this affects the everyday life of workers, both in the workplace and at home. If inequalities are indeed exacerbated, it is important to show how both the health crisis and the attempt to manage it have distinct effects on workers, both globally and within specific national settings.

\section{To what extent has the pandemic and responses to it engendered new or revived forms of resistance and organisation among workers?}

The crisis is also revealing novel forms of resistance by newly visible sectors of workers, most importantly the demand for better protection from infection risks and for the temporary closure of workplaces where the virus has been spreading. As early as the beginning of February this year, 2500 healthcare workers in Hong Kong walked out to demand the closure of the border with China as a protective measure (Barron, 2020; Ramzy and May, 2020). In March, there was a crosssectoral strike wave in Italy that affected a number of big manufacturers (Pontarelli, 2020; Tamma, 2020). Roughly around the same time, there were numerous localised strikes and protests in the United States in different sectors, including construction, retail and delivery workers (Fung, 2020; Gurley, 2020a, 2020b; Haag, 2020). In the assembly plants along Mexico's northern border with the United States, which had experienced an enormous strike wave in early 2019, workers are now engaged in strikes to protest the lack of health and safety measures (London and Lobo, 2020).

An interactive map hosted by Payday Report shows over 200 wildcat strikes across the United States since the beginning of March 2020 (Cheadle, 2020). These range from calling in sick en masse, to refusing to show up for work, to stoppages lasting a few hours until management responds to workers' demands. The striking workers are from diverse workplaces such as meat and fruit packing, delivery, sanitation, retail, fast-food restaurants, prisons, manufacturing and naval shipyards. They include truckers, graduate students, detainees in the custody of Immigration and Customs Enforcement (ICE), children of meat packers, dining-room workers at universities, hospital courier services, nursing homes ... the list goes on. Reasons for the strikes range from work intensification, low pay, no compensation for extra work, no paid breaks, and lack of workplace safety and necessary resources to protect oneself and family members from COVID19. While some of the strikers belong to unions, many do not. According to Mike Elk, the founder of Payday Report, workers can be afraid to strike, fearing the loss of their jobs, but during the pandemic the reason to strike is more fundamental: workers are afraid that they might lose their lives. By showing the spread of these strikes across the United States, Elk believes that it might be possible to "open the door to more widespread organizing campaigns and other union activity.... Once workers realize they have power, they don't forget it" (Cheadle, 2020).

All of this raises a range of questions for labour scholars: Are we likely to see new organising 
efforts emerge from the current strike wave, or will massive unemployment further weaken unions or organising activities? Could fragmented local wildcat strikes scale up towards larger transformative trans-local solidarities and labour actions? What should be the methodology to examine these disparate strikes and forms of labour unrest? Can we deploy the conceptualisation of forms of "contagion", developed by Beverly Silver (2003) and the World Labour Research Group, to map the uneven topography of labour actions to develop an analytical and political understanding? Or do we need an interdisciplinary approach that foregrounds agency, contexts, life stories and oral histories to understand the processes that engender labour mobilisation and resistance and the possibilities of transformative politics?

\section{To what extent are we likely to see significant political shifts and realignments as a result of the pandemic, and what are the consequences likely to be for workers?}

One important theme we are likely to see this crisis will be the struggle to control and redefine dominant institutions in economics, politics and society. On the one hand, there is the tendency to bail out the big corporations and industries, to strengthen authoritarian and nationalist tendencies, to divide the population and to exacerbate existing inequalities. On the other hand, we are also beginning to observe new possibilities for addressing climate change, new bases of support for restructuring health and education systems, new civil society initiatives, and new political leadership. In the United States, for example, which is politically divided and confronting the pandemic in an election year, the depth of the economic and health crisis might make possible the consideration of more radical political positions than before, with regard to such issues as health insurance, worker rights and protections, education, immigration, social welfare and climate.

National responses to the pandemic reveal both the strengths and shortcomings of existing policies, institutions and governments. In countries where economic growth was weak and democracies were absent or already under threat, the pandemic is likely to exacerbate those conditions, further destabilising economies and politics. The pandemic has provided some governments with the pretext to rule by decree, to further restrict civil liberties and to suspend elections. Even in established democracies, the destabilising effects of the pandemic may expand the political space for right-wing political formations.

Some governments with strong centralised responses to the pandemic have received broad public support, while in others weak central responses have highlighted political divisions and the fractured nature of the polity. The different approaches cut across political regimes that are democratic and authoritarian, on the left and on the right. For instance, in Australia and New Zealand public support appeared for centralised responses by political leaders of very different ideological leanings (Cave, 2020). In Vietnam and the Indian State of Kerala, the epidemic was brought under control relatively quickly; both are long-time Communist strongholds (Jones, 2020; Kurian, 2020). Public support also emerged for the pandemic response of more divisive nationalist leaders like Narendra Modi in India (Gettleman and Yasir, 2020).

Are cases like these more likely to see continuity with the status quo ante rather than dramatic political realignments? Or will it depend on governments' handling of the economic impacts of the pandemic, including whether social policies exist to mitigate those impacts? Each of the multiple phases of the pandemic - lockdown, reopening, recurring restrictions - as well as long-term economic and labour market impacts, are likely to pose new challenges for governments and societies and new points of struggle.

Clearly, any political shifts will have significant impacts on workers. Any restriction of democracy, any move to the right, is likely to prove harmful to workers, who rely on democratic 
systems and civil liberties to defend and advance their interests - in the workplace, on the streets and in parliaments. To the extent that the political space opens for new ideas that diminish inequality and expand democracy, workers are likely to benefit. In this scenario, could the public revalorisation of "essential workers" lead to broader protections and better pay for low-wage workers? Might the value of immigrant workers be recognised? Could unions play a bigger role in the redesign of policies and institutions? Will there be a greater focus on extending forms of social protection to previously excluded sectors of workers? Or will we instead see governments and employers use the economic crisis and mass unemployment to suppress workers' demands, strikes, organising efforts and basic rights? Will the economic challenges be so great that it will be years before countries are able to address the increases in poverty, inequality, joblessness and precarious work?

\section{How does the use of digital infrastructures implemented in this crisis alter the labour process? What is their impact on workers?}

We can expect a technological leap facilitated by the coronavirus crisis. The current tendency towards digitalisation and automation will accelerate. Some of these ideas are prefigured in political strategies - for example, the recent French-German initiative by Emmanuel Macron and Angela Merkel in May 2020 (Bundesregierung, 2020). German multinational Siemens has just announced that it is splitting off its significant energy business from the main company in order to focus on digital industries, remaining only as a minority shareholder in the energy section (Hegmann, 2020). The current mass dismissals of core workforces - such as the announcement by Boeing in late April 2020 to cut 10 per cent of its workforce, or of Uber on 26 May 2020 to cut 25 per cent of its workforce in India - are paving the way for this acceleration (Financial Times, 2020a, 2020b). Arguably, this would have happened anyway sooner or later, but the current crash in demand is allowing large companies to fast-track the introduction of new technologies. This might be accompanied by a rapid concentration of capital given the bankruptcy of many small and medium enterprises; the amount of capital necessary for digitalisation is much higher than in earlier waves of technological restructuring. Thus, this crisis could also hit the remaining core workforces with stable salaries and secure contracts very hard.

For labour scholars, this calls for a re-examination of how recently implemented digital infrastructures change the organisation of work - for example, by shifting it into homes - and what this means for workers. What kind of mechanisms of surveillance and control are workers exposed to? What does working from home imply for the reproduction of labour power? How can workers organise and engage in resistance to employer control if they are disciplined with the help of digital technologies or work in isolation?

\section{How does the pandemic, and its political and economic effects, affect attempts to address the global ecological crisis, and what does this mean for workers?}

According to some commentators, the global pandemic is connected to the global ecological crisis (Gills, 2020; Satgar, 2020). They argue that the continued encroachment of human settlements into natural habitats and the exploitation of nature through the poaching of wild animals have exposed humankind to dangerous pathogens. In this sense, the health crisis has exposed the fragility of "society-nature relationships" (Brand and Wissen, 2013) under capitalist conditions, and the material force of the pandemic has demonstrated, once more, the urgent need to address the ecological crisis. The lockdowns may have led to a drastic reduction in carbon emissions, and even 
Trump ordered General Motors to produce ventilators. But with a deep economic crisis looming, there is a danger that governments will choose to protect polluting industries rather than facilitate industrial conversion. The Merkel government has decided to bail out the German national carrier Lufthansa to the tune of 9 billion euros, and Macron has announced that his government will spend roughly the same amount of money to support the ailing French car industry (Mallet, 2020; Sweeney, 2020).

For labour, this heightens already existing tensions and dilemmas. On the one hand, many workers, especially in manufacturing, depend for their livelihood on industries that deplete natural resources and contribute significantly to carbon emissions. On the other hand, workers have a considerably smaller carbon footprint than people on higher incomes both in the Global North and South (Boucher, 2016; Wiederhofer et al., 2017), and they have fewer material resources with which they can protect themselves from its fallout.

Against this backdrop, labour scholars might ask how the global pandemic affects the jobs of workers in polluting industries, whether digitalisation and automation create opportunities for a "greening" of work, whether new opportunities are emerging for industrial conversion, and what the prospects are for red-green alliances to facilitate a social-ecological transformation of society.

\section{What might be the implications of the crisis for labour scholars around the world? How are universities and research centres being transformed, and with what effects?}

Labour scholars are workers, who are usually employed by universities or academic research bodies. Many are also active trade unionists or labour activists. It follows that their work falls under the remit of global labour studies, all the more since it raises politically and academically relevant questions around the relationship between scholarship and activism. The proliferation of precarious labour in academia and the forms in which academics have organised and mobilised to fight casualisation have been discussed on the pages of this Journal before (see the January 2018 issue). In light of the current changes to universities, it is worth revisiting this topic.

In countries with fully marketised university systems, the financial impact of the crisis is already drastic. As there are fewer students - and particularly fewer "lucrative" out-of-state or international students paying higher fees - the revenue created by these universities is dwindling. Universities in Australia, Britain, Canada and the United States have already announced layoffs (Blunt, 2020; McKie, 2020). But even universities that are mostly state-funded, which still can be found in many continental European countries, may suffer severely from budget cuts once governments try to reduce the public debt incurred through bailouts and fiscal expansion during the first phase of the crisis. Consequently, commentators see the crisis as an existential threat to the existing university system and a prelude to a deep transformation of academia. There are fears that the shift to online teaching, combined with a funding crisis, will lead to drastic job cuts because it will allow fewer professors to reach more students with their lectures, that large tech companies will capture and swallow higher education, and that the already significant inequalities in access to higher education will widen even more (Galloway, 2020; Ivancheva and Swartz, 2020; O'Hara, 2020).

In light of this, it is worth conducting empirical research on the reality on the ground. How does the shift to online teaching change the academic labour process? What does this mean for decision-making concerning academic work and hierarchies in academia? What are the implications for jobs and employment relations, and is the trend towards casualisation being reinforced? What are the reactions of unions and labour activists, and how do they mobilise resistance? What are the 
effects on students, and is there a prospect of alliances between students and university staff? What are the class effects of the transformation of the university and the implications for the divide between mental and manual labour?

\section{Contemporary Perspectives on Labour}

This editorial reflects our initial responses to what is very likely the early stage of a long and drawnout health and economic crisis. As our thoughts here indicate, this moment, like all crises, is potentially productive for labour scholars and workers' movements in terms of political possibilities, theoretical insights and strategic innovations. We welcome submissions in the coming months that continue to engage with the issues we have raised here, as well as other approaches to the intersection of labour and the current crisis.

This issue of the Global Labour Journal contains a special section of topical Global Issues pieces, which we are publishing as part of our ongoing commemoration of the tenth anniversary of the Journal. We will publish another round of these pieces in the Global Issues section of the September issue. These sections were planned before the pandemic. Our initial idea was to invite labour scholars to reflect on topics which are important for understanding the contemporary world of work, but which have received relatively little attention in the Global Labour Journal and in global labour studies in general. This was inspired by the fact that recent years have seen a proliferation of rich debates in a range of topics - such as race and class, nationalism, social reproduction and the climate crisis - which are directly relevant to issues of labour. Yet, these debates and topics have largely remained distinct from the labour studies literature. In communicating with our authors, we mentioned topics we were interested in, but we also gave them a great deal of freedom to decide the focus and format of their interventions.

The published pieces reflect this freedom. Some of them are brief and broadly pitched theoretical interventions, such as Phoebe Moore's analysis of the intersection between artificial intelligence and workers, while others are more empirically focused analyses of particular issues, such as Archana Prasad's piece on communal violence and informal labour in Delhi. Some authors have chosen to engage with the coronavirus crisis through the lens of their topic, such as Alessandra Mezzadri's piece on social reproduction, but others have not done so. We hope that you find these pieces as interesting and provocative as we have, and we look forward to publishing another set of these as we conclude our tenth anniversary commemoration in the September issue this year.

\section{REFERENCES}

ABC News (2020) Coronavirus Cluster at Melbourne Abattoir Cedar Meats Grows to 98. ABC, 16 May 2020. https://www.abc.net.au/news/2020-05-16/victoria-coronavirus-cases-update-cedar-meatsabattoir-cluseter/12254862 [accessed 26 May 2020].

Bacon, D. (2020) Following Mexico's Worker Strikes, the US Steps in to Keep Border Factories Open. Janata Weekly, 17 May 2020. http://janataweekly.org/following-mexicos-worker-strikes-the-us-steps-into-keep-border-factories-open [accessed 26 May 2020].

Barron, L. (2020) This Shouldn't Be About Politics: Hong Kong Medical Workers Call for Border Shutdown Amid Coronavirus Outbreak. Time, 4 February 2020. https://time.com/5777285/hong-kongcoronavirus-border-closure-strike [accessed 26 May 2020].

Beech, H. (2020) Singapore Seemed to Have Coronavirus Under Control, Until Cases Doubled. New York Times, 20 April 2020. https://www.nytimes.com/2020/04/20/world/asia/coronavirus-singapore. 
html? searchResultPosition=3 [accessed 26 May 2020].

Bergfeld, M. (2020) The Insanity of Making Sick People Work. Jacobin, 3 May 2020. https://jacobinmag.com/2020/03/coronavirus-workers-rights-health-care-cleaners-gig-economy [accessed 26 May 2020].

Birke, P. and F. Bluhm (2020) Migrant Labour and Workers' Struggles: The German Meatpacking Industry as Contested Terrain. Global Labour Journal, 10(1): 34-51.

Blauer Montag (2020) Vom Notstand der Arbeitsgesellschaft. Sozial.Geschicbte Online. https://sozial geschichteonline.files.wordpress.com/2020/04/sgo 27 vorverc3b6ffentlichung blauer montag krise -1.pdf [accessed 26 May 2020].

Blunt, M. (2020) Manitoba Universities, Colleges Laying Off Staff Amid Provincial Funding Cuts. Global News, 12 May 2020. https://globalnews.ca/news/6936067/coronavirus-manitoba-universities-collegesfunding-cuts [accessed 26 May 2020].

Bogoeski, V. (2020) The German Asparagus Saga. International Politics and Society, 1 May 2020. https://www.ips-journal.eu/regions/europe/article/show/the-german-asparagus-saga-4321 [accessed 26 May 2020].

Bonanese, A. (2020) Die gesamte Lebensmittelproduktion könnte ins Stocken greaten. Der Spiegel, interview, 1 April 2020. https://www.spiegel.de/politik/ausland/ernte-in-italien-gesamte-lebensmittelproduk tion-koennte-ins-stocken-geraten-a-f140723a-ac3b-48b1-801d-34f33cbae3c1 [accessed 26 May 2020].

Boucher, J.L. (2016) Culture, Carbon, and Climate Change: A Class Analysis of Climate Change Belief, Lifestyle Lock-in, and Personal Carbon Footprint. Socijalna Ekologija, 25(1): 53-80.

Brand, U. and M. Wissen (2013) Crisis and Continuity of Capitalist Society-Nature Relationships: The Imperial Mode of Living and the Limits to Environmental Governance. Review of International Political Economy, 20(4): 687-711.

Bundesregierung (2020) A French-German Initiative for the European Recovery from the Coronavirus Crisis. Press release, 18 May 2020. https:/ / www.bundesregierung.de/resource/blob/973812/1753772/ 414a4b5a1ca91d4f7146eeb2b39ee72b/2020-05-18-deutsch-franzoesischer-erklaerung-engdata.pdf?download=1 [accessed 26 May 2020].

Cave, D. (2020). Vanquish the Virus? Australia and New Zealand Aim to Show the Way. New York Times, 24 April 2020. https://www.nytimes.com/2020/04/24/world/australia/new-zealand-coronavirus. html [accessed 26 May 2020].

Cheadle, H. (2020) Coronavirus Has Caused More Than 150 Strikes: This Map Is Tracking Them All. Vice, 29 April 2020. https://www.vice.com/en us/article/k7e4gn/coronavirus-has-caused-more-than-150strikes-this-map-is-tracking-them-all [accessed 26 May 2020].

Comisión Económica para América Latina y el Caribe (CEPAL)/Organización Internacional del Trabajo (OIT) (2020) El trabajo en tiempos de pandemia: desafíos frente a la enfermedad por coronavirus (COVID-19). Coyuntura Laboral en América Latina y el Caribe, No 22 (LC/TS.2020/46), Santiago, May 2020. https://www.ilo.org/wcmsp5/groups/public/---americas/---ro-lima/---sro-santiago/docu ments/publication/wcms 745573.pdf [accessed 26 May 2020].

Dutch News (2020) Dutch Meat Processing Plant Closed as 45 Workers Test Positive for Covid-19. 21 May 2020. https://www.dutchnews.nl/news/2020/05/dutch-meat-processing-plant-closed-as-45-workers-testpositive-for-covid-19/ [accessed 27 May 2020].

Economist Intelligence Unit (EIU) (2020). Coronavirus: The Impact on Global Supply Chains. 19 March 2020. Available at: https://www.eiu.com/industry/article/479237431/coronavirus-the-impact-on-globalsupply-chains/2020-03-19 [accessed 26 May 2020].

Financial Times (2020a) Uber Cuts 25\% of India Workforce as Virus Halts Growth. Financial Times, 26 May 2020. https://www.ft.com/content/80f83cb6-8a94-48eb-9346-b6bb4ee7c5ab [accessed 26 May 2020].

Financial Times (2020b) Boeing Cuts Jobs and Production as Coronavirus Slashes Demand. Financial Times, 29 April 2020. https://www.ft.com/content/dd9b99c0-21e3-45b6-8d69-deef13f4f956 [accessed 26 
May 2020].

France24 (2020) France Hit by New Covid-19 Outbreaks in Two Abattoirs. 18 May 2020. https://www.france24. com/en/20200518-france-hit-by-new-covid-19-outbreaks-in-two-abattoirs [accessed 26 May 2020].

Frew, N. (2020) Suitcases Full of Cash Offered at PPE Factories Overseas Affecting Global Supply. CBC News, 18 May 2020. https://www.cbc.ca/news/canada/manitoba/canada-ppe-supplier-manufacturer1.5573108 [accessed 26 May 2020].

Fung, B. (2020) Amazon Fires Warehouse Worker who led Staten Island Warehouse Walkout. CNN, 31 March 2020. https://edition.cnn.com/2020/03/30/tech/amazon-worker-fired-staten-island-ware house/index.html [accessed 29 May 2020].

Galloway, S. (2020) The Coming Disruption. NY Mag, interview, 11 May 2020. https://nymag.com/ intelligencer $/ 2020 / 05 /$ scott-galloway-future-of-college.html [accessed 26 May 2020].

Gettleman, J. and S. Yasir (2020) Modi's Popularity Soars as India Weathers the Pandemic. New York Times, 16 May 2020. https://www.nytimes.com/2020/05/16/world/asia/coronavirus-modi-india.html [accessed 25 May 2020].

Gills, B. (2020) Deep Restoration: from the Great Implosion to the Great Awakening. Globalizations, 17(4): 577-579.

Golden, S.H. (2020) Coronavirus in African Americans and Other People of Color. Health, 20 April 2020. https://www.hopkinsmedicine.org/health/conditions-and-diseases/coronavirus/covid19-racialdisparities [accessed 26 May 2020].

Grierson, J. (2020) Anti-Asian Hate Crimes UP 21\% in UK during Coronavirus Crisis. The Guardian, 13 May 2020. https://www.theguardian.com/world/2020/mav/13/anti-asian-hate-crimes-up-21-in-uk-during -coronavirus-crisis [accessed 26 May 2020].

Gurley, L.K. (2020a) Instacart's Gig Workers are Planning a Massive, Nationwide Strike. Vice, 27 March 2020. https://www.vice.com/en_us/article/4agmvd/instacarts-gig-workers-are-planning-a-massivenationwide-strike [accessed 26 May 2020].

Gurley, L.K. (2020b) Whole Foods Employees are Staging a Nationwide "Sick-Out". Vice, 30 March 2020. https://www.vice.com/en us/article/5dmeka/whole-foods-employees-are-staging-a-nationwide-sickout [accessed 26 May 2020].

Haag, M. (2020) Virus Rules Let Construction Workers Keep Building Luxury Towers. New York Times, 29 May 2020. https://www.nytimes.com/2020/03/25/nyregion/coronavirus-nyc-construction.html [accessed 26 May 2020].

Haedicke, M. (2020) How Coronavirus Threatens the Seasonal Farmworkers at the Heart of the American Food Supply. The Conversation, 3 April 2020. https://theconversation.com/how-coronavirus-threatensthe-seasonal-farmworkers-at-the-heart-of-the-american-food-supply-135252 [accessed 26 May 2020].

Hegmann, G. (2020) Siemens wird gespalten. Kaesers Angst vor dem Angriff von Amazon. Die Welt, 26 May 2020. https://www.welt.de/wirtschaft/plus208393177/Siemens-Kaesers-Angst-vor-dem-Angriff. html [accessed 26 May 2020].

Human Rights Watch (2020) Covid-19 Fueling Anti-Asian Racism and Xenophobia Worldwide. Human Rights Watch, 12 May 2020. https://www.hrw.org/news/2020/05/12/covid-19-fueling-anti-asianracism-and-xenophobia-worldwide [accessed 26 May 2020].

International Labour Organization (ILO) (2020) As Job Losses Escalate, Nearly Half of Global Workforce at Risk of Losing Livelihoods. Press release, 29 April 2020. https://www.ilo.org/global/about-theilo/newsroom/news/WCMS 743036/lang--en/index.htm [accessed 29 May 2020].

Ivancheva, M. and R. Swartz (2020) Universities Go Online during the Pandemic: Who Reaps the Profits? Coronatimes, 19 May 2020. https://www.coronatimes.net/universities-go-online-pandemic-profits/ [accessed 26 May 2020].

Jones, A. (2020) Coronavirus: How “'Overreaction” Made Vietnam a Virus Success. BBC.com, 15 May 2020. https://www.bbc.com/news/world-asia-52628283 [accessed 26 May 2020]. 
Jordan, M. (2020) Farmworkers, Mostly Undocumented, Become "Essential" during Pandemic. New York Times, 10 April 2020. https://www.nytimes.com/2020/04/02/us/coronavirus-undocumentedimmigrant-farmworkers-agriculture.html [accessed 26 May 2020].

Jordan, M. and C. Dickerson (2020) Poultry Worker's Death Highlights Spread of Coronavirus in Meat Plants. New York Times, 9 April 2020. https://www.nytimes.com/2020/04/09/us/coronaviruschicken-meat-processing-plants-immigrants.html?action $=$ click\&module $=$ Top $\% 20$ Stories\&pgtype $=$ Homepage [accessed 26 May 2020].

Kotecha, V. (2019) The NHS's Workforce Shortages Illustrate the UK's Dependence on Migrant Labour. Centre for Health and the Public Interest, 19 July 2019. https:// chpi.org.uk/blog/the-nhss-workforce-shortagesillustrate-the-uks-dependence-on-migrant-labour [accessed 26 May 2020].

Kundu, P. (2020) COVID-19 Crisis Will Push Millions of Vulnerable Children into Child Labour. The Wire, 21 April 2020. https://thewire.in/rights/covid-19-crisis-will-push-millions-of-vulnerable-children-into -child-labour [accessed 26 May 2020].

Kurian, O. (2020) How the Indian State of Kerala Flattened the Coronavirus Curve. The Guardian, 21 April 2020. https://www.theguardian.com/commentisfree/2020/apr/21/kerala-indian-state-flattened-coro navirus-curve [accessed 26 May 2020].

Lakhani, N. (2020) US Coronavirus Hotspots Linked to Meat Processing Plants. The Guardian, 15 May 2020. https://www.theguardian.com/world/2020/may/15/us-coronavirus-meat-packing-plants-food [accessed 26 May 2020].

Levitt, T. (2020) “A Terrible Way to Go for $£ 9$ an Hour": Fear at Meat Plant after Three Coronavirus Deaths. The Guardian, 20 May 2020. https://www.theguardian.com/environment/2020/may/20/its-aterrible-way-to-go-for-9-an-hour-fear-at-meat-plant-after-three-deaths-coronavirus [accessed 26 May 2020].

Lewis, H. (2020) The Coronavirus is a Disaster for Feminism. The Atlantic, 19 March 2020. https://www.the atlantic.com/international/archive/2020/03/feminism-womens-rights-coronavirus-covid19/608302/ [accessed 26 May 2020].

Linthicum, K., W. Fry and G. Minjares (2020) The US is Pushing Mexico to Reopen Factories even as Workers Die of Covid-19. LA Times, 30 April 2020. https://www.latimes.com/world-nation/story/ 2020-04-30/as-more-workers-die-from-covid-19-the-u-s-is-pressuring-mexico-to-re-open-borderfactories [accessed 26 May 2020].

London, E. (2020) Nach der Rückkehr an die Arbeitsplätze: Hunderte mexikanische Maquiladora-Arbeiter gestorben. World Socialist Website, 20 May 2020. https://www.wsws.org/de/articles/2020/05/20/maqum20.html [accessed 26 May 2020].

London, E. and A. Lobo (2020) Streiken gegen den Tod: Mexikanische Maquiladora-Arbeiter legen Arbeit nieder. World Socialist Website, 22 April 2020. https://www.wsws.org/de/articles/2020/04/22/mexia22.html [accessed 29 May 2020].

Mallet, V. (2020) Emmanuel Macron Injects €8bn to Fuel French Car Industry Revival. Financial Times, 26 May 2020. https://www.ft.com/content/8e84e13b-d02f-4d90-839d-f99c3a0c1d95 [accessed 27 May 2020].

Mano, A. (2020) Nine Meat Plants in Southern Brazil Face COVID-19 Outbreaks. Reuters, 30 April 2020. https://www.reuters.com/article/us-health-coronavirus-brazil-meatpackers/nine-meat-plants-insouthern-brazil-face-covid-19-outbreaks-idUSKBN22C2J8 [accessed 26 May 2020].

Marx, K. (1976 [1867]) Capital, Volume 1. London: Penguin.

McKie, A. (2020) Covid-19: Universities Treating Staff in "Vastly Different Ways". Times Higher Education, 20 May 2020. https://www.timeshighereducation.com/news/covid-19-universities-treating-staff-vastly -different-ways \#\%20 [accessed 26 May 2020].

McSweeney, E. (2020) Covid-19 Outbreaks at Irish Meat Plants Raise Fears over Worker Safety. The Guardian, 1 May 2020. https://www.theguardian.com/environment/2020/may/01/covid-19-out breaks-at-irish-meat-plants-raise-fears-over-worker-safety [accessed 26 May 2020]. 
National Employment Law Project (NELP) (2017) Raises from Coast to Coast in 2018: Workers in 18 States and 19 Cities and Counties Seeing Minimum Wage Increases on January 1, Many of Them to Rates of $\$ 12$ to $\$ 15$ an Hour. https://www.nelp.org/publication/raises-from-coast-to-coast-in-2018-minimum-wage-increases/ [accessed 26 May 2020].

Niehus, R., P.M. de Salazar, A.R. Taylor and M. Lipsitch (2020) Estimating Underdetection of Internationally Imported COVID-19 Cases. Medrxiv, 14 February 2020. https://www. medrxiv.org/content/10.1101/2020.02.13.20022707v1.full.pdf [accessed 26 May 2020].

Nuffield Trust (2019) One in Four Hospital Staff Born Outside the UK, New Nuffield Trust Analysis Reveals. 4 December 2019. https://www.nuffieldtrust.org.uk/news-item/one-in-four-hospital-staff-born-outside -the-uk-new-nuffield-trust-analysis-reveals [accessed 26 May 2020].

O'Hara, G. (2020) Universities are on the Brink of Crisis. Coronavirus May Tip Them over the Edge. The Guardian, 21 May 2020. https://www.theguardian.com/commentisfree/2020/may/21/universitiesbrink-crisis-coronavirus-pandemic-tuition-fees [accessed 26 May 2020].

Pandey, V. (2020) Coronavirus Lockdown: The Indian Migrants Dying to Get Home. BBC News, 20 May 2020. https://www.bbc.com/news/world-asia-india-52672764 [accessed 26 May 2020].

Pontarelli, F. (2020) Covid-19: Labour Movement Struggles to Institute Social Distance between Capital's Need and People's Health in Italy. Global Labour Column, March 2020. http://column.global-labouruniversity.org/2020/03/covid-19-labour-movement-struggles-to.html [accessed 26 May 2020].

Rao, N. (2020) India's Coronavirus Lockdown Will Hit Women and Migrant Workers Hardest. The Conversation, 26 March 2020. https://theconversation.com/indias-coronavirus-lockdown-will-hitwomen-and-migrant-workers-hardest-134689 [accessed 26 May 2020].

Ramzy, A. and T. May (2020) Hong Kong Tightens Border as Medical Workers Call for Shutdown. New York Times, 5 February 2020. https://www.nytimes.com/2020/02/03/world/asia/hong-kongcoronavirus-china-border.html [accessed 26 May 2020].

Ratcliffe, R. (2020a) Singapore's Cramped Migrant Worker Dorms Hide Covid-19 Surge Risk. The Guardian, 17 April 2020. https://www.theguardian.com/world/2020/apr/17/singapores-cramped-migrantworker-dorms-hide-covid-19-surge-risk [accessed 29 May 2020].

Ratcliffe, R. (2020b) "We're in a Prison": Singapore's Migrant Workers Suffer as Covid-19 Surges Back. The Guardian, 23 April 2020. https://www.theguardian.com/world/2020/apr/23/singapore-millionmigrant-workers-suffer-as-covid-19-surges-back [accessed 29 May 2020].

Reuters (2020) Italy to Offer Permits to Illegal Migrants for Farm Work in Covid Crisis. Reuters, 5 May 2020. https://www.reuters.com/article/us-health-coronavirus-italy-migrants/italy-to-offer-permits-to-illegal -migrants-for-farm-work-in-covid-crisis-idUSKBN22H1NF [accessed 26 May 2020].

Sarter, K.V., D. Sack and S. Fuchs (2014) Public Procurement as Social Policy? https://www.unibielefeld.de/soz/powi/pdf/WPCG01 Sarter Sack Fuchs Public Procurement Aug14.pdf [accessed 26 May 2020].

Satgar, V. (2020) Covid-19, Climate Crisis and Lock Down - An Opportunity to End the War with Nature. Daily Maverick, 25 March 2020. https://www.dailymaverick.co.za/article/2020-03-25-covid-19-theclimate-crisis-and-lockdown-an-opportunity-to-end-the-war-with-nature [accessed 26 May 2020].

Scheiber, N., N. Schwartz and T. Hsu (2020) "White-Collar Quarantine" over Virus Spotlights Class Divide. New York Times, 27 March 2020. https://www.nytimes.com/2020/03/27/business/economy/ coronavirus-inequality.html [accessed 26 May 2020].

Silver, B. (2003) Forces of Labor: Workers' Movements and Globalization Since 1870. Cambridge: Cambridge University Press.

Staudemaier, D.W. (2020) Germany Agrees Stricter Meat Industry Regulation Following Coronavirus Outbreaks. DW, 20 May 2020. https://www.dw.com/en/germany-agrees-stricter-meat-industryregulations-following-coronavirus-outbreaks/a-53510078 [accessed 26 May 2020].

Sweeney, M. (2020) Lufthansa Agrees €9bn Bailout with German Government. The Guardian, 26 May 2020. 
https://www.theguardian.com/business/2020/may/26/lufthansa-9bn-bailout-german-governmentcoronavirus-flights [accessed 26 May 2020].

Tamma, P. (2020) Coronavirus Sparks Nationwide Strikes in Italy. Politico, 13 March 2020. https://www. politico.eu/article/coronavirus-sparks-nationwide-strikes-in-italy/ [ accessed 26 May 2020].

Tolbert, J., K. Orgera and A. Damico (2019) Key Facts about the Uninsured Population. KFF, 13 December 2019. https://www.kff.org/uninsured/issue-brief/key-facts-about-the-uninsured-population [accessed 26 May 2020].

Wiedenhofer, D., D. Guan, Z. Liu, J. Meng, N. Zhang and Y.-M. Wei (2016) Unequal Household Carbon Footprints in China. Nature Climate Change, 7(1): 75-80. 